\title{
Antifungal and Antioxidant Activities of Vernonia Chalybaea Mart. ex DC. Essential Oil and their Major Constituent $\beta$-caryophyllene
}

Antonio Carlos Nogueira Sobrinho ${ }^{1}$

http://orcid.org/0000-0002-9921-3350

\section{Selene Maia de Morais ${ }^{1,5 *}$}

https://orcid.org/0000-0002-2766-3790

Elnatan Bezerra de Souza ${ }^{2}$

https://orcid.org/0000-0002-5222-4378

\author{
Maria Rose Jane Ribeiro Albuquerque ${ }^{3}$ \\ https://orcid.org/0000-0002-3558-4566
}

\author{
Hélcio Silva dos Santos ${ }^{3}$ \\ https://orcid.org/0000-0001-5527-164X
}

\author{
Carolina Sidrim de Paula Cavalcante ${ }^{4}$ \\ https://orcid.org/0000-0001-9559-6799 \\ Halisson Araújo de Sousa ${ }^{5}$ \\ https://orcid.org/0000-0002-7481-5208
}

\author{
Raquel Oliveira dos Santos Fontenelle ${ }^{2}$ \\ https://orcid.org/0000-0003-1133-6231
}

${ }^{1}$ Ceara State University, Postgraduate Program in Biotechnology-Renorbio, Faculty of Veterinary Medicine, Fortaleza, Brazil. ${ }^{2}$ Vale do Acaraú State University, Biological Sciences Course, Center for Agrarian and Biological Sciences, Sobral, Brazil. ${ }^{3}$ Vale do Acaraú State University, Chemistry Course, Center for Exact Sciences and Technology, Sobral, Brazil. ${ }^{4}$ Federal University of Ceara, Faculty of Pharmacy, Dentistry and Nursing, Fortaleza, Brazil. ${ }^{5}$ Ceara State University, Chemistry Course, Science and Technology Center, Fortaleza, Brazil.

Received: 2019.05.24; Accepted: 2020.02.13.

*Correspondence: selenemaiademorais@gmail.com; Tel.: +55-85-988938645 (F.L.)

HIGHLIGHTS

- $\quad \beta$-caryophyllene, bicyclogermacrene, caryophyllene oxide are major constituents.

- Essential oil and $\beta$-caryophyllene potentiated the effect of ketoconazole.

- The essential oil and major constituent showed antioxidant activities.

- Totally eleven sesquiterpenes were identified in Vernonia chalybaea essential oil.

Abstract: This article describes the chemical composition of Vernonia chalybaea essential oil, and investigates its antimicrobial, antioxidant and hemolytic activities. The evaluation of the antifungal activity was performed by the broth microdilution method using strains of yeasts and dermatophytic fungi. The checkerboard technique to find antimicrobial modulatory effects was performed using ketoconazole as standard drug. The antioxidant activity was evaluated by DPPH scavenging assay and $\beta$-carotene/linoleicacid system. The toxicity was characterized by the brine shrimp lethality test and hemolysis bioassays. The essential oil was obtained by hydrodistillation and analyzed by GC-MS method, showing to be rich in the sesquiterpenes $\beta$-caryophyllene (39.06\%) and bicyclogermacrene (19.69\%), and also demonstrated a relevant antifungal activity against strains of Trichophyton rubrum. In the modulatory activity assay, the essential oil of $V$. chalybaea and $\beta$-caryophyllene demonstrated a synergistic interaction with ketoconazole, with increasing of its antifungal action. The antioxidant activity was evidenced mainly by $\beta$-carotene/linoleic acid system, with $\mathrm{IC}_{50}$ value of $35.87 \pm 0.32 \mu \mathrm{g} / \mathrm{mL}$. The results suggest that $V$. chalybaea essential oil and $\beta$-caryophyllene are valuable natural medicinal agents with antioxidant and antimicrobial activities. 
Keywords: Lepidaploa chalybaea; Trichophyton rubrum; Sesquiterpene hydrocarbons; Antidermatophytic activity; Natural antioxidants.

\section{INTRODUCTION}

Vernonia species are found in tropical and sub-tropical areas, especially in South America, Asia and Africa. Several Vernonia species have been investigated revealing many properties, such as antiplasmodial, analgesic, anti-inflammatory, antimicrobial, anti-diabetes, antitumor, antioxidant and have been used as well for treatment of several microbial diseases, as snakebite antidote, and as food in some African regions [1]. Furthermore, the genus Vernonia has a commercial potential and included as new oilseed crop species [2].

Vernonia chalybaea Mart. ex DC. [syn. Lepidaploa chalybaea (Mart. ex DC.) H.Rob.] is a common species in South America, known in Brazil by many names, such as "cheira-bode", "balaio" and "vassourinha", endemic in Brazil with distribution in the Southeast and Northeast of the country, especially in regions of Caatinga (shrub lands) and rocky grasslands [3]. V. chalybaea is used to treat edema and liver disease in Latin-American folk medicine [4].

Previous studies reported the isolation of the sesquiterpene lactone glaucolide B from aerial parts of $V$. chalybaea [5] and investigated the antimicrobial activity against strains of Gram-positive and Gram-negative bacteria, yeasts and Cladosporium cladosporioides [6]. A study of Burim and coauthors [7] has shown that glaucolide $\mathrm{B}$ has cytotoxic and clastogenic activity.

The chemical investigation of the hexane and ethanol extracts from aerial parts of $V$. chalybaea conducted to the isolation and characterization of a new aliphatic tetrahydroxyl ether, along with a series of known compounds such the triterpenes $4 \alpha, 10 \alpha$-epoxyaromadendrane, friedelin, taraxasteryl acetate, pseudotaraxasteryl acetate, lupeyl acetate, lupeol, $\alpha$-amiryn, $\beta$-amiryn; steroids as $\beta$-sitosterol, stigmasterol, and the flavonoids angophorol, angophorol-7-O-glucoside, angophorol-7-O-rutinoside, 3,7-dimethoxy-5,3',4'trihydroxyflavone and acacetin [8]. These reports demonstrated a significant pharmacological and medicinal potential of $V$. chalybaea due to active compounds present in the plant extracts.

The therapeutic properties of many plants are supported by their chemical components, especially those isolated from extracts and essential oils, which often exhibit the ability to scavenge free radicals [9, 10].

Essential oils are frequently used in traditional medicine as antimicrobial agents, for their antiseptic action [11]. Many of these essential oils are rich in phenolic compounds, like phenylpropanoids and terpenoids, like eugenol and thymol, respectively of which antioxidant and antimicrobial activities are well documented [12, 13].

Then, the aim of this study was to investigate the biological potential of $V$. chalybaea essential oil (VCEO) and major constituent $\beta$-caryophyllene by analyzing the antioxidant and antifungal activities, including modulation activity assays with a standard antifungal drug and evaluates hemolytic action and toxicity against Artemia salina.

\section{MATERIAL AND METHODS}

\section{Chemicals}

All chemicals (if not stated otherwise) were obtained from Sigma-Aldrich Co (St. Louis, MO, USA), at the highest available grades.

\section{Plant material}

The botanical material used in this study (aerial parts) were collected in the flowering period in municipality of Alcântaras, in the Meruoca mountain region, Ceará, Brazil, in June 2014, in a semideciduous forest environment located around $800 \mathrm{~m}$ above sea level (latitude $3^{\circ} 3^{\prime} 3^{\prime \prime} \mathrm{S}$, longitude 40ํ 40' 40" W). A voucher specimen (No. 3106) was deposited in the Francisco José de Abreu Matos Herbarium (HUVA) and authenticated by Dr. Elnatan Bezerra de Souza of the Center for Agricultural Sciences and Biological Sciences, State University of Vale do Acaraú.

\section{Isolation and analysis of the essential oil}

Fresh aerial parts of $V$. chalybaea $(640 \mathrm{~g})$ were subjected to hydrodistillation for $4 \mathrm{~h}$ in a modified Clevenger-type apparatus [14]. The oil was dried over anhydrous Na2SO4 ( 1 g), filtered and preserved in a sealed vial at $4 \stackrel{\circ}{\circ}$ prior to further analysis, with a yield of $0.1 \%(\mathrm{w} / \mathrm{w})$. The chemical analysis of the essential oils constituents was performed with a Shimadzu QP-2010 Ultra instrument employing the following 
conditions: column: Rtx-5MS (Crossbond 5\%, diphenyl/95\% dimethyl polysiloxane) with $30 \mathrm{~m} \times 0.25 \mathrm{~mm} \times$ $0.25 \mu \mathrm{m}$ df; carrier gas: $\mathrm{He}(24,2 \mathrm{~mL} / \mathrm{min}$, in constant linear velocity mode); the injector temperature was $250^{\circ} \mathrm{C}$, in split mode $(1: 100)$, and the detector temperature was $250^{\circ} \mathrm{C}$. The column temperature was programmed $35-180^{\circ} \mathrm{C}$ at $4 \stackrel{\circ}{\circ} \mathrm{C} / \mathrm{min}$ then $180-280^{\circ} \mathrm{C}$ at $17^{\circ} \mathrm{C} / \mathrm{min}$, and at $280 \stackrel{\circ}{\circ}$ for $10 \mathrm{~min}$; mass spectra: electron impact $70 \mathrm{eV}$. The sample was injected in volume of $1 \mu \mathrm{L}$. The identity of the components was achieved from their GC retention times, calculated by linear interpolation relative to retention times of main compounds and by comparison of their mass spectra with those present in the computer data bank (NIST) and published literature [15].

\section{Antifungal assay}

The antifungal activity was determined by the broth microdilution method, in accordance to M27-A3 (yeasts) and M38-A (filamentous fungi) guidelines of Clinical and Laboratory Standards Institute [16, 17]. Trichophyton rubrum strains were obtained from the fungal collection of the Microbiology Laboratory, State University of Vale do Acaraú, and URM Culture Collection of the Department of Mycology, Federal University of Pernambuco, and Candida spp. strains from Hospital Santa Casa de Misericórdia de Sobral. A total of 4 strains of $T$. rubrum, 2 strains of $C$. albicans, 1 strain of $C$. parapsilosis and 1 strain of C. tropicalis. Standardized inocula (2.5-5 x 103 CFU mL-1 for Candida spp. and $5.0 \times 104$ CFU mL-1 for T. rubrum) were prepared by turbidimetry. Aliquot suspension were prepared in potato dextrose agar (Difco, Detroit, MI, USA), and then incubated at $28{ }^{\circ} \mathrm{C}$ for $2-10$ days. The suspensions were diluted to 1:2000 for Candida spp. and 1:500 for T. rubrum, both with RPMI 1640 medium with I-glutamine without sodium bicarbonate, and then buffered to $\mathrm{pH} 7.0$ with $0.165 \mathrm{M}$ MOPS. The minimum inhibitory concentration (MIC) and minimum fungicidal concentrations (MFC) were determined according Fontenelle and coauthors [18] and CLSI guidelines document $[16,17]$. The VCEO and $\beta$-caryophyllene were prepared in $100 \%$ mineral oil. Amphotericin B (AMB) and ketoconazole (KTC) were prepared in DMSO. Ketoconazole and amphotericin B (standard antifungals) were placed in concentrations ranging from $16 \mu \mathrm{g} / \mathrm{mL}$ to $0.125 \mu \mathrm{g} / \mathrm{mL}$. For the antimicrobial activity, the essential oil samples were tested in concentrations ranging from 0.002 to $2.5 \mathrm{mg} / \mathrm{mL}$. The microdilution test was performed in 96 -well microdilution plates incubated at $37^{\circ} \mathrm{C}$, and antifungal effect was analyzed visually after 2 days for Candida spp. and 5 days for T. rubrum. The MFC was determined by subculturing $100 \mu \mathrm{L}$ of solution from wells without turbidity on potato dextrose, at $28^{\circ} \mathrm{C}$. The MFCs were determined as the lowest concentration resulting in no growth on the subculture after 2 days for Candida spp. and 5 days for T. rubrum.

\section{Microdilution checkerboard assay}

The modulatory activity was determined on all T. rubrum strains by checkerboard technique [19, 20]. Interaction of the drugs was determined by calculating the Fractional Inhibitory Concentration Index (FICl). Fractional Inhibitory Concentration (FIC) was defined with the MIC values of each drug in the combination divided by the MIC of the drug alone. The turbidity of the fungal suspensions was adjusted to $0.5 \mathrm{McF}$ arland standard (105 CFU $/ \mathrm{mL}$ ). The products were used at concentrations of their respective MICs. $50 \mu \mathrm{L}$ of RPMI 1640 medium was added to the wells of 96 wells microdilution plate. Then $50 \mu \mathrm{L}$ of each dilution of natural product was added in vertical orientation, with the concentrations ranging from $5 \mathrm{mg} / \mathrm{mL}$ to $0.03 \mathrm{mg} / \mathrm{mL}$. In the horizontal orientation, $50 \mu \mathrm{L}$ of ketoconazole (standard antifungal) was placed in concentrations ranging from $16 \mu \mathrm{g} / \mathrm{mL}$ to $0.125 \mu \mathrm{g} / \mathrm{mL}$. $100 \mu \mathrm{L}$ from suspension of $T$. rubrum $(5.0 \times 104 \mathrm{CFU} \mathrm{mL-1)}$ was added to all wells and incubated at $37^{\circ} \mathrm{C}$ for 5 days. Assays were performed in triplicate. The $\mathrm{FICl}$ was interpreted as synergistic effect at values $\leq 0.5$, an indifferent effect at values $>0.5$ or $\leq 4.0$, and an antagonistic effect at values $>4.0[19,21]$.

\section{DPPH (1,1-diphenyl-2-picrylhydrazyl) radical scavenging activity}

Concentrations of the samples in $10000-1 \mu \mathrm{g} / \mathrm{mL}$ were prepared for the mixture of $0.1 \mathrm{~mL}$ aliquots with $3.9 \mathrm{~mL}$ of DPPH methanol solution $(6.5 \times 10-5 \mathrm{M})$ for $1 \mathrm{~h}$ of reaction. The test was performed in triplicate and after $1 \mathrm{~h}$, the absorbance of the mixture was measured at $515 \mathrm{~nm}$ by spectrophotometry [22]. The medium inhibitory concentration (IC50) was calculated in the Origin 7.0 statistic program.

\section{$\beta$-carotene/linoleic acid assay}

This assay was described by Lopes-Lutz and coauthors [23] and Andrade and coauthors [24]. A stock solution of emulsion was prepared with $1 \mathrm{mg}$ of $\beta$-carotene dissolved in $5 \mathrm{~mL}$ of chloroform $(0.3 \mathrm{mg} / \mathrm{mL}), 200$ $\mu \mathrm{L}$ of Tween 40 and $20 \mu \mathrm{L}$ of linoleic acid. Chloroform was completely evaporated using a vacuum evaporator. 
After, $100 \mathrm{~mL}$ of oxygenated distilled water was added and emulsified for $1 \mathrm{~min}$ in a sonificator to form emulsion. The solution was adjusted in the spectrophotometer $(470 \mathrm{~nm})$. The final emulsion had absorbance between $0.6 \mathrm{~nm}$ and $0.7 \mathrm{~nm}$. Aliquots of $100 \mu \mathrm{l}$ of oil sample were dissolved in methanol, at concentrations of $500 \mu \mathrm{g} / \mathrm{mL}$ to $25 \mu \mathrm{g} / \mathrm{mL}$, and then we added $5-\mathrm{mL}$ of $\beta$-carotene/linoleic acid emulsion. The sample absorbance was measured after $2 \mathrm{~min}$, then the samples were subjected to oxidation by placing in an oven at $50{ }^{\circ} \mathrm{C}$ for $120 \mathrm{~min}$, and a second reading was performed. The $\beta$-carotene/linoleic acid emulsion was used as negative control. As positive controls were used the oxygenated monoterpenes thymol and carvacrol (concentrations of $500 \mu \mathrm{g} / \mathrm{mL}$ to $25 \mu \mathrm{g} / \mathrm{mL}$ ), present in many essential oils. Each assay was performed in triplicate. IC50 values were defined as concentration sufficient to obtain $50 \%$ of a maximum effect estimate in $100 \%$, and were calculated by the linear regression equation of the concentration of the essential oil and $\beta$-caryophyllene.

\section{Brine shrimp lethality bioassay}

The bioassay using Artemia salina Leach larvae (Crustacea, Artemiidae) was modified from the assay performed according to Meyer and coauthor [25]. Brine shrimp eggs were incubated at room temperature (between $22-29^{\circ} \mathrm{C}$ ) in artificial sea water for 48 hours. The essential oil was dissolved in methanol, DMSO, and saline water in concentrations of $1000,100,10$ and $1 \mu \mathrm{g} / \mathrm{mL}$. Then 10 shrimps were added to test tubes containing $5 \mathrm{~mL}$ of each tested solution and negative and positive control solutions. Potassium dichromate $\left(\mathrm{K}_{2} \mathrm{Cr}_{2} \mathrm{O}_{7}\right)$ dissolved in saline solution and saline solution with DMSO were used as positive and negative controls, respectively in concentrations of $1000 \mu \mathrm{g} / \mathrm{mL}$ to $1 \mu \mathrm{g} / \mathrm{mL}$. This assay was performed in triplicate and the number of dead larvae was counted after contact for 24 hours. The percentage mortality and LC50 values was obtained by linear regression using the GraphPad Prism software 5.0 program.

\section{Hemolysis assay}

In this assay were used human red blood cells to determine cytotoxicity from essential oil in accordance as described to Ahmad and coauthors [26]. Blood samples were obtained from Sysmex (RocheTM) as hematological control sample from individuals with normal hematological parameters. An aliquot of $10 \mathrm{~mL}$ of fresh blood was collected in EDTA tubes, and then centrifuged at $2000 \mathrm{rpm}$ for $10 \mathrm{~m}$ at $20^{\circ} \mathrm{C}$. After plasma removal, the pellet containing the human erythrocytes was washed five times with PBS and then resuspended in PBS to obtain an $8 \%(\mathrm{v} / \mathrm{v})$ suspension. Then was added $100 \mu \mathrm{L}$ of this suspension to different microcentrifuge tubes with $100 \mu \mathrm{L}$ of 2 -fold serial dilutions of essential oil, ranging from 0.005 to $2.5 \mathrm{mg} / \mathrm{mL}$. Final concentrations were $4 \%(\mathrm{v} / \mathrm{v})$ of erythrocyte suspension and the essential oil concentration range was 0.1-100 $\mu \mathrm{M}$. The resulting suspensions were incubated with agitation for $60 \mathrm{~min}$ at $37^{\circ} \mathrm{C}$. After incubation, the solutions were centrifuged for $2 \mathrm{~min}$ at $1000 \mathrm{~g}$. The supernatants were transferred to 96 -well plates and the hemoglobin release was measured by absorbance spectrophotometrically $(540 \mathrm{~nm})$. Triton X-100 at $1 \%$ and $4 \%(\mathrm{v} / \mathrm{v})$ human erythrocytes in PBS with no essential oil (untreated) were used as positive and negative controls, respectively. Percentage hemolysis was determined as [(Abs540nm sample-treated - Abs540nm untreated)/ (Abs540nm1\% Triton X-100 - Abs540nm untreated)] x 100, and experiments were carried out in triplicate.

\section{Statistical analysis}

All experiments were performed in triplicate. One-way ANOVA with the Tukey test was performed followed by multiple comparison testing where appropriate. IC50 values were performed with GraphPad Prism software 5.0 (GraphPad Software, San Diego, CA). Significance of difference was accepted at $p<0.05$.

\section{RESULTS}

The essential oil yield of $V$. chalybaea (VCEO) was $0.1 \%$ (w/w - dry weight). Relative percentages of individual components of the VCEO in Table 1 were obtained from the GC-MS peak area-percent report. Chemical analysis of the essential oil revealed the presence of eleven sesquiterpenes, accounting for $91.94 \%$. The main constituents were $\beta$-caryophyllene (39.06\%), bicyclogermacrene (19.69\%), caryophyllene oxide $(8.69 \%)$ and $\beta$-elemene (8.25). Except for caryophyllene oxide all other constituents were sesquiterpene hydrocarbons. 
Table 1. Chemical constituents of the essential oil from Vernonia chalybaea (VCEO)

\begin{tabular}{lcc}
\hline Compound $^{\text {a }}$ & KI & VCEO \\
\hline$\beta$-Elemene & 1389 & 8.25 \\
iso-Italicene & 1392 & 1.26 \\
cis-Bergamotene & 1392 & 0.47 \\
$\beta$-Caryophyllene & 1427 & 39.06 \\
epi-ß-Santalene & 1445 & 0.49 \\
$\alpha$-Humulene & 1450 & 4.92 \\
Bicyclogermacrene & 1499 & 19.69 \\
Spathulenol & 1580 & 6.79 \\
Caryophyllene oxide & 1583 & 8.69 \\
Globulol & 1591 & 1.62 \\
Humulene epoxide II & 1610 & 0.70 \\
Total identified compounds & & 91.94 \\
\hline r of elution on DB-5 capillary column. ${ }^{b}$ Kovats retention index [15]
\end{tabular}

In the broth microdilution assay against dermatophytes and yeasts, the VCEO only inhibited the growth of dermatophytes, with MIC values of $1.25 \mathrm{mg} / \mathrm{mL}$ for all tested strains of $T$. rubrum. The results are summarized in Table 2. The tests showed that the VCEO did not significantly inhibit the growth of any of the tested yeasts (C. albicans LABMIC 0101, C. albicans LABMIC 0102, C. tropicalis LABMIC 0102 and C. parapsilosis LABMIC 0113).

Table 2. Minimum inhibitory concentration (MIC) and minimum fungicidal concentration (MFC) of essential oils from $V$. chalybaea (VCEO) and $\beta$-caryophyllene against Candida spp and T. rubrum

\begin{tabular}{|c|c|c|c|c|c|}
\hline \multirow{2}{*}{ Strains } & \multicolumn{2}{|c|}{ VCEO } & \multicolumn{2}{|c|}{$\beta$-caryophyllene } & Drug $(\mu \mathrm{g} / \mathrm{mL})$ \\
\hline & $\begin{array}{c}\text { MIC } \\
(\mathrm{mg} / \mathrm{mL})\end{array}$ & $\begin{array}{c}\text { MFC } \\
(\mathrm{mg} / \mathrm{mL})\end{array}$ & $\begin{array}{c}\text { MIC } \\
(\mathrm{mg} / \mathrm{mL})\end{array}$ & $\begin{array}{c}\text { MIC } \\
(\mathrm{mg} / \mathrm{mL})\end{array}$ & $\begin{array}{c}\text { Amphotericin } \\
\text { B/Ketoconazo } \\
\text { le }\end{array}$ \\
\hline C. albicans LABMIC 0101 & $\mathrm{NI}$ & $\mathrm{NI}$ & $\mathrm{NI}$ & $\mathrm{NI}$ & 2.0 \\
\hline C. albicans LABMIC 0102 & $\mathrm{NI}$ & $\mathrm{NI}$ & $\mathrm{NI}$ & $\mathrm{NI}$ & 2.0 \\
\hline C. tropicalis LABMIC 0102 & $\mathrm{NI}$ & $\mathrm{NI}$ & $\mathrm{NI}$ & $\mathrm{NI}$ & 2.0 \\
\hline $\begin{array}{c}\text { C. parapsilosis LABMIC } \\
0113\end{array}$ & $\mathrm{NI}$ & $\mathrm{NI}$ & $\mathrm{NI}$ & $\mathrm{NI}$ & 2.0 \\
\hline T. rubrum LABMIC 0201 & 1.25 & 2.5 & 1.25 & 2.5 & 1.0 \\
\hline T. rubrum LABMIC 0202 & 1.25 & 2.5 & 0.625 & 1.25 & 1.0 \\
\hline T. rubrum LABMIC 0203 & 1.25 & 2.5 & 1.25 & 2.5 & 1.0 \\
\hline T. rubrum LABMIC 0204 & 1.25 & 2.5 & 1.25 & 2.5 & 1.0 \\
\hline Geometric mean & 1.25 & 2.5 & 1.05 & 2.1 & - \\
\hline
\end{tabular}

$\mathrm{NI}$, no inhibition of fungal growth. LABMIC, Microbiology Laboratory. Amphotericin B used for yeast and ketoconazole for dermatophytes.

In testing the modulatory activity, four T. rubrum strains were used. The results are shown in Table 3. The combination of VCEO with ketoconazole showed that there was a significant reduction in MIC values for essential oil against both strains, as well as significant reduction in the MIC of ketoconazole, from 1.0 to 0.25 , for the strain $T$. rubrum LABMIC 0202. From these values, we calculated the fractional inhibitory concentration index $(\mathrm{FICl})$, which showed a synergistic effect on the modulatory activity of strain $T$. rubrum LABMIC 0202 with $\mathrm{FICI}$ value of 0.3 and an indifferent effect in the tests with strain T. rubrum LABMIC 0201, whose $\mathrm{FICl}$ value was 1.0 . 
Table 3. MIC of the ketoconazole in the presence and absence of essential oil from Vernonia chalybaea (VCEO) and $\beta$-caryophyllene against dermatophyte strains.

\begin{tabular}{|c|c|c|c|}
\hline Natural product/Drug & $\begin{array}{c}\text { MIC }(\mu \mathrm{g} / \mathrm{mL}) \\
\text { Alone }\end{array}$ & $\begin{array}{c}\text { MIC }(\mu \mathrm{g} / \mathrm{mL}) \\
\text { Combined }\end{array}$ & FIC index \\
\hline & \multicolumn{3}{|c|}{ LABMIC 0201 ( T. rubrum) } \\
\hline VCEO & 1250 & 39 & \multirow[t]{2}{*}{0.5} \\
\hline Ketoconazole & 1.0 & 0.5 & \\
\hline$\beta$-caryophyllene & 1250 & 19.5 & \multirow[t]{2}{*}{0.5} \\
\hline Ketoconazole & 0.25 & 0.125 & \\
\hline & \multicolumn{3}{|c|}{ LABMIC 0202 ( T. rubrum) } \\
\hline VCEO & 1250 & 78 & 0.3 \\
\hline Ketoconazole & 1.0 & 0.25 & \multirow{3}{*}{0.5} \\
\hline$\beta$-caryophyllene & 625 & 19.5 & \\
\hline Ketoconazole & 0.25 & 0.125 & \\
\hline & \multicolumn{3}{|c|}{ LABMIC 0203 (T. rubrum) } \\
\hline$\beta$-caryophyllene & 1250 & 19.5 & \multirow[t]{2}{*}{0.2} \\
\hline Ketoconazole & 2 & 0.5 & \\
\hline & \multicolumn{3}{|c|}{ LABMIC 0204 (T. rubrum ) } \\
\hline$\beta$-caryophyllene & 1250 & 19.5 & \multirow[t]{2}{*}{0.2} \\
\hline Ketoconazole & 1 & 0.25 & \\
\hline
\end{tabular}

a FIC index, index fractional inhibitory concentration (FICl)

$\beta$-caryophyllene demonstrated capacity of modulatory activity against all dermatophytes strains, especially for the $T$. rubrum LABMIC 0203 and T. rubrum LABMIC 0204, whose FICI value was 0.2 . These results obtained showed significant synergistic antifungal activity when combined $\beta$-caryophyllene with ketoconazole on the growth inhibition of dermatophytes.

The antioxidant potentials of VCEO and $\beta$-caryophyllene were investigated by the free radical DPPH (1,1-diphenyl-2-picrylhydrazyl) scavenging assay and $\beta$-carotene/linoleic-acid oxidation model system. IC50 values are shown in Table 4.

Table 4. Antioxidant activity of the essential oil from Vernonia chalybaea (VCEO), $\beta$-caryophyllene and the thymol and carvacrol, tested standards

\begin{tabular}{ccc}
\hline $\begin{array}{c}\text { Methods/ } \\
\text { Compound }\end{array}$ & $\begin{array}{c}\boldsymbol{\beta} \text {-carotene / linoleic } \\
\text { acid }\end{array}$ & DPPH \\
\hline VCEO & $\mathrm{IC}_{50}(\mu \mathrm{g} / \mathrm{mL})$ & $\mathrm{IC}_{50}(\mu \mathrm{g} / \mathrm{mL})$ \\
$\beta$-Caryophyllene & $35.87 \pm 0.32$ & $249.68 \pm 1.01$ \\
Thymol & $42.99 \pm 0.88$ & $98.74 \pm 0.78$ \\
Carvacrol & $11.32 \pm 0.55$ & $21.71 \pm 0.16$ \\
\hline
\end{tabular}

$\mathrm{IC}_{50}$ is defined as the concentration sufficient to obtain $50 \%$ of a maximum effect estimate in $100 \%$.

The essential oil exhibited weak antioxidant capacity in the DPPH radical scavenging assay, with IC50 value of $249.68 \pm 1.01 \mu \mathrm{g} / \mathrm{mL}$, well above the standards, which were the oxygenated monoterpene thymol, whose IC50 was $21.71 \pm 0.16 \mu \mathrm{g} / \mathrm{mL}$ and carvacrol $(25.5 \pm 0.58 \mu \mathrm{g} / \mathrm{mL})$. However, the results were favorable for antioxidant effect in the $\beta$-carotene/linoleic-acid assay, preventing the oxidation of linoleic acid. In this assay, the IC50 of the essential oil was $35.87 \mu \mathrm{g} / \mathrm{mL}$ while that of thymol was $11.32 \pm 0.55 \mu \mathrm{g} / \mathrm{mL}$ and carvacrol was $22.83 \pm 0.98 \mu \mathrm{g} / \mathrm{mL}$. These results characterize the hydrocarbon terpenic nature of compounds with apolar interactions similarity to $\beta$-carotene.

In the lethality assay of the VCEO with $A$. salina nauplii, the concentration required to kill $50 \%$ (LC50) was $29.96 \pm 0.77 \mu \mathrm{g} / \mathrm{mL}$. In vitro hemolytic activity assay of VCEO at concentrations $0.039,0.078,0.156$, $0.312,0.625,1.25$ and $2.5 \mathrm{mg} / \mathrm{mL}$ showed the percentage of hemolysis ranged from $0.1 \%$ to $4.89 \%$ (Figure 1). Based on these results, and by extrapolation of hemolysis values the IC50 of $69.01 \pm 0.78 \mathrm{mg} / \mathrm{mL}$ was estimated for the essential oil. Regarding hemolytic activity, the statistical analysis showed a significant difference at the level $p=0.05$ when compared to the positive control Triton X-100 with the VCEO concentrations used. 


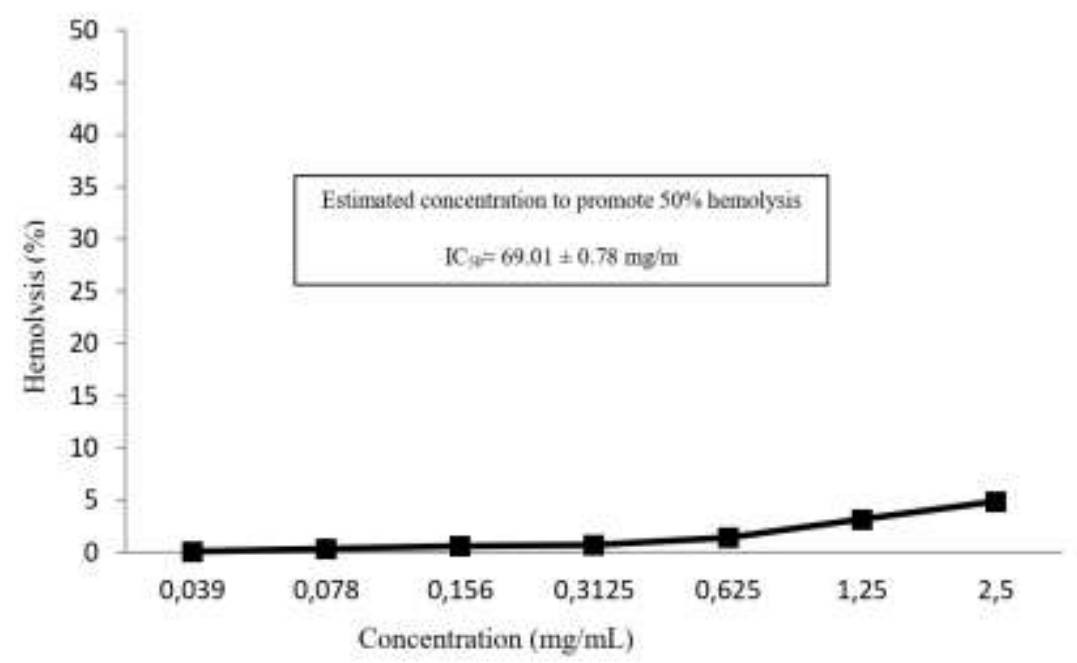

Figure 1. Hemolytic activity of the essential oil from Vernonia chalybaea. (VCEO)

\section{DISCUSSION}

A previous study of the chemical composition of the essential oil of the aerial parts of $V$. chalybaea [27] identified 23 components, representing $87.3 \%$ of the total content identified, with the presence of mono- and sesquiterpenes in similar proportions $(46.8 \%$ and $40.5 \%)$, the main constituents being $\beta$-pinene $(30.6 \%)$ and $\beta$-caryophyllene (12.1\%). The difference in the essential oil composition in relation the previous study can be explained by many variables such as daily variations caused by the circadian cycle of the plant or the seasonal changes due to weather differences [28], water availability [29], ultraviolet radiation [30], nutrients [31], altitude [32] and mechanical stimuli [33]. Although the collections were carried out in the same region, they were collected at different points and at different times of the year.

Other studies have reported a biological potential of some of the major components found in the VCEO. Pharmacological trials demonstrated analgesic action [34] and antispasmodic action [35] of $\beta$-caryophyllene. Another constituent, bicyclogermacrene, has antimicrobial activity against Gram-positive and Gram-negative bacteria [36] and deuteromycete fungus Cladosporium sphaerospermum [37], which is one of the most commonly isolated airborne contaminants, responsible for the casuistry of cerebral and cutaneous phaehyphomycosis [38].

$\beta$-caryophyllene, major constituent of VCEO, is a bicyclic sesquiterpene with a rare 1,1dimethylcyclobutane ring, commonly found in many essential oils from several plants, such as Zingiber nimmonii (J.Graham) Dalzell [39], Copaifera reticulata Ducke [40] and Eupatorium ballotifolium Kunth [41]. $\beta$-caryophyllene has been commonly used as a fragrance and flavouring agent in citrus flavors, soaps, spice blends, creams and lotions, detergents, and also in a variety of beverages and food products [42]. The antibacterial activity has been reported for several bacterial strains [43-45], thus increasing their antimicrobial potential.

There are no reports on the antimicrobial activity of $V$. chalybaea species. Therefore, this work describes for first time the antifungal activity in vitro of its essential oil against the dermatophyte $T$. rubrum. This fungus is responsible for clinical skin infections, dermatophytosis. It has high affinity for keratin protein and is one of the most prevalent fungi in the etiology of these contagious infections in humans [46], accounting for $80 \%$ of cases of onychomycosis [47].

Antifungal activity of $\beta$-caryophyllene [48-50], bicyclogermacrene [37] and caryophyllene oxide [48, 51] were reported in previous studies. These results indicate that the antifungal activity found in our study may represent a combined effect of these sesquiterpenes of the VCEO.

The modulatory activity results show that the combined use the natural product VCEO and $\beta$ caryophyllene with ketoconazole reduced the MIC of this antifungal agent. This result indicates that these natural products have an effect on strains of the dermatophyte T. rubrum, suggesting that modulatory activity tests should be conducted with other filamentous fungi that are human pathogens. A possible mechanism for the inhibition of microbial growth can be the hydrophobic nature of the constituents of natural products, which can act on the plasma membrane, making it more permeable to antifungal agents and thereby affecting the biochemical apparatus of the respiratory chain and of energy production [52]. $\beta$-caryophyllene is a hydrophobic molecule, which presents low molecular weight; these properties facilitate the permeability in the cellular membrane of the fungi, being able to be involved in the mechanism of action of inhibition of 
microbial growth. This work is the first investigating modulatory activity of VCEO and $\beta$-caryophyllene combination with and potentiation on antifungal agent.

The $\beta$-carotene/linoleic-acid oxidation system is an assay based on the bleaching of $\beta$-carotene due to oxidation induced by oxidative degradation products of linoleic acid. This assay is employed mainly to investigate the antioxidant capacity of lipophilic substances, such as essential oils [53,54]. This method is also suitable to determine the antioxidant activity of thermo-sensitive substances such as essential oils, since it does not require high temperatures [55].

Studies involving antioxidant activity of compounds isolated from plants have shown the antioxidant action of sesquiterpenes [56,57]. A study of the essential oil from aerial parts of Eupatorium ballotifolium identified 25 components, while the $\beta$-caryophyllene was the main constituent (23.59\%). It was demonstrated the antioxidant and antifungal activities of the essential oil, and suggested that the high level of sesquiterpene hydrocarbons, $\beta$-caryophyllene (23.59\%), germacrene D (6.56\%) and bicyclogermacrene $(6.47 \%)$, is related to the biological activities [41].

This can explain the antioxidant action found in VCEO, considering that its essential oil's chemical composition was mainly sesquiterpenes (76.93\%). $\beta$-caryophyllene, the main constituent found, was previously shown to have antioxidant activity and protective effect on liver fibrosis and ability to inhibit activation of hepatic stellate cells [58]. The antioxidant action reported can be related with the synergistic effect between sesquiterpene hydrocarbons, main constituents from essential oil [59]. The Vernonia genus presents great biotechnological potential, due to the antioxidant properties reported in this work and in other species, such as $V$. amygdalina Delile [60,61], V. patula Mart. ex Baker [62], V. cinerea (L.) Less. [63] and $V$. condensata Baker [64].

The $\beta$-caryophyllene in the DPPH scavenging assay exhibited a moderated antioxidant capacity, however when compared to the VCEO, the major constituent demonstrated a better result. In the $\beta$-carotene / linoleic acid test, $\beta$-caryophyllene showed a better antioxidant capacity to protect the emulsion between $\beta$ carotene and linoleic acid in the system. The DPPH radical scavenging assay is commonly used to evaluate the antioxidant activity of more polar compounds such as phenols and flavonoids $[53,65]$.

Studies involving antioxidant properties of natural products are relevant when interpreted together with antimicrobial assays, since antioxidant substances are efficient free radical stabilizers, helping to strengthen the immune system, an important feature in the development of bioproducts with antimicrobial action.

Bioassays with $A$. salina are largely used due to the fast results that correlate with potential biological activities and therefore indicate biological activity [66]. Toxicity tests with $A$. salina present good correlation with antimicrobial activity $[67,68]$. The LC50 value (less than $1000 \mu \mathrm{g} / \mathrm{mL}$ ) of the VCEO indicates that it has significant biological activity [25], as demonstrated in this work.

The determination of hemolytic activity of a substance helps determine its cytotoxic effect. Methods to determine the hemolytic activity in vitro consist of checking for potential damage of substances present in essential oils on the membranes of erythrocytes, in particular to cause lysis, releasing hemoglobin in the medium [69]. A percentage of $4.89 \%$ hemolysis was observed at the MIC values of the essential oil. Based on antifungal activity results, the essential oil concentration responsible for the bioactivity is less when compared to that needed to damage erythrocytes by membrane rupture. Therefore, the VCEO showed low cytotoxic action according to the test of hemolytic activity.

\section{CONCLUSION}

The essential oil from Vernonia chalybaea contains only sesquiterpenes, which can be responsible for its antioxidant and antifungal properties. This interaction was synergistic, reducing the MIC values of both substances tested, modulating their antifungal actions against strains of dermatophytes. These results indicate that the essential oil and main constituent $\beta$-caryophyllene potentiate the antifungal action of ketoconazole suggesting a possible utilization of these compounds in addition to antifungal drugs for the treatment of mycoses. Hence, this study of chemical and biological characterization of the essential oil of $V$. chalybaea points out the biotechnological potential of this plant species, corroborating with popular medicine and ethnomedicinal uses in skin infections.

Acknowledgments: The authors gratefully to the Postgraduate Program in Biotechnology-Renorbio of State University of Ceará, the financial support of CAPES and FUNCAP-CE No. 3781047/2017, the Laboratory of Natural Products Chemistry of State University of Ceará and to the Microbiology Laboratory of State University of Vale do Acaraú.

Conflicts of Interest: All authors have no conflict of interest to declare. 


\section{REFERENCES}

1. Sobrinho ACN, Souza EB, Fontenelle ROS. A review on antimicrobial potential of species of the genus Vernonia (Asteraceae). J Med Plants Res. 2015; 9: 838-850.

2. Cruz VMC, Dierig DA. Trends in literature on new oilseed crops and related species: Seeking evidence of increasing or waning interest. Ind Crop Prod. 2012; 37: 141-148.

3. Dematteis M, Almeida G. Lepidaploa in Lista de Espécies da Flora do Brasil. Jardim Botânico do Rio de Janeiro. http://floradobrasil.jbrj.gov.br/jabot/floradobrasil/FB27134. 2018.

4. Albuquerque UP, Medeiros PM, Almeida ALS, Monteiro JM, Neto EMFL, Melo JG, Santos JP. Medicinal plants of the Caatinga (semi-arid) vegetation of NE Brazil: a quantitative approach. J Ethnopharmacol. 2007; 114: 325-354.

5. Bohlmann F, Zdero C, King RM, Robinson H. Hirsutinolides and other sesquiterpene lactones from Vernonia species. Phytochemistry. 1982; 21: 695-699.

6. Lopes JLC. Sesquiterpene lactones from Vernonia. Mem Inst Oswaldo Cruz. 1991; 86: 227-230.

7. Burim RV, Canalle R, Lopes JLC, Takahashi CS. Genotoxic action of the sesquiterpene lactone glaucolide B on mammalian cells in vitro and in vivo. Genet Mol Biol. 1999; 22: 401-406.

8. Costa FJ, Bandeira PN, Albuquerque MRJR, Pessoa ODL, Silveira PER, Braz-Filho R. Constituintes químicos de Vernonia chalybaea Mart. Quim Nova. 2008; 31: 1691-1695.

9. Granato D, Shahidi F, Wrolstad R, Kilmartin P, Melton LD, Hidalgo FJ, Miyashita K, Camp J, Alasalvar C, Ismail AB, Elmore F, Birch GG, Charalampopoulos D, Astley SB, Pegg R, Zhou P, Finglas P. Antioxidant activity, total phenolics and flavonoids contents: Should we ban in vitro screening methods?. Food Chemistry, 2018; 264: $471-$ 475.

10. Morais SM, Lima KSB, Siqueira SMC, Cavalcanti ESB, Souza MST, Menezes JESA, Trevisan MTS. Correlação entre as atividades antiradical, antiacetilcolinesterase e teor de fenóis totais de extratos de plantas medicinais de farmácias vivas. Rev Bras PI Med. 2013; 15: 575-582.

11. Bakkali F, Averbeck S, Averbeck D, Idaomar M. Biological effects of essential oils-a review. Food Chem Toxicol. 2008; 46: 446-475.

12. Achika JI, Arthur DE, Gerald I, Adedayo A. A review on the phytoconstituents and related medicinal properties of plants in the Asteraceae family. IOSR J Appl Chem. 2014; 7: 1-8.

13. Raut JS, Karuppayil SM. A status review on the medicinal properties of essential oils. Ind Crop Prod. 2014; 62: 250-264.

14. Craveiro AA, Matos FJA, Alencar JW. A simple and inexpensive steam generator for essential oils extraction. J Chem Educ 1976; 53: 652.

15. Adams RP. Identification of Essential Oil Components by Gas Chromatography/Mass Spectrometry. Allured Publishing Corporation, Illinois, 2012.

16. Clinical and Laboratory Standards Institute. Reference Method for Broth Dilution Antifungal Susceptibility Testing of Yeasts (Approved Standard. Document M27. CLSI). Third ed. vol. M27-A3. Clinical and Laboratory Standards Institute, Wayne, PA, 2008a.

17. Clinical and Laboratory Standards Institute. Reference Method for Broth Dilution Antifungal Susceptibility Testing of Filamentous Fungi (Approved Standard. Document M38. CLSI). Second ed. vol. M38-A2. Clinical and Laboratory Standards Institute, Wayne, PA, 2008b.

18. Fontenelle ROS, Morais SM, Brito EHS, Brilhante RSN, Cordeiro RA, Nascimento NRF, Kerntopf MR, Sidrim JJC, Rocha MFG. Antifungal activity of essential oils of Croton species from the Brazilian Caatinga biome. J Appl Microbiol. 2008; 104: 1383-1390.

19. Johnson MD, MacDougall C, Ostrosky-Zeichner L, Perfect JR, Rex JH. Combination antifungal therapy. Antimicrob Agents Chemother. 2004; 48: 693-715.

20. Pyun MS, Shin S. Antifungal effects of the volatile oils from Allium plants against Trichophyton species and synergism of the oils with ketoconazole. Phytomedicine. 2006; 13: 394-400.

21. Odds FC. Synergy, antagonism, and what the chequerboard puts between them. J. Antimicrob Chemother. 2003; 52: 1-1.

22. Yepez B, Espinosa M, López S, Bolanos G. Producing antioxidant fractions from herbaceous matrices by supercritical fluid extraction. Fluid Phase Equilib. 2002; 194: 879-884.

23. Lopes-Lutz D, Alviano DS, Alviano CS, Kolodziejczyk PP. Screening of chemical composition, antimicrobial and antioxidant activities of Artemisia essential oils. Phytochemistry. 2008; 69: 1732-1738.

24. Andrade MA, Cardoso MDG, Batista LR, Mallet ACT, Machado SMF. Óleos essenciais de Cymbopogon nardus, Cinnamomum zeylanicum e Zingiber officinale: composição, atividades antioxidante e antibacteriana. Rev Ciênc Agron. 2012; 43: 399-408.

25. Meyer BN, Ferrigni NR, Putnam JE, Jacobsen LB, Nichols DJ, McLaughlin JL. (). Brine shrimp: a convenient general bioassay for active plant constituents. Planta Med. 1982; 45: 31-4.

26. Ahmad A, Khan A, Manzoor N, Khan LA. Evolution of ergosterol biosynthesis inhibitors as fungicidal against Candida. Microb Pathog. 2010; 48: 35-41.

27. Albuquerque MRJR, Souza EB, Mesquita EF, Nunes EP, Cunha NA, Silveira ER. Volatile Constituentes from Leaves of Vernonia chalybaea Mart. and Eupatorium ballotaefolium HBK. J Essent Oil Res. 2001; 13: 376-377.

28. Palá-Paúl J, Pérez-Alonso MJ, Velasco-Negueruela A, Palá-Paúl R, Sanz J, Conejero, F. Seasonal variation in chemical constituents of Santolina rosmarinifolia L. ssp. rosmarinifolia. Biochem. Sys Ecol. 2001; 29: 663-672. 
29. Waterman PG, Mole S. Analysis of phenolic plant metabolites. Blackwell Scientific Publications: Oxford. 1994, cap. 3.

30. Ioannidis $\mathrm{D}$, Bonner $\mathrm{L}$, Johnson CB. UV-B is required for normal development of oil glands in Ocimum basilicum $\mathrm{L}$. (Sweet Basil). Ann Bot. 2002; 90: 453-460.

31. Sharafzadeh S, Khosh-Khui M, Javidnia K. Effect of nutrients on essential oil components, pigments and total phenolic content of lemon balm (Melissa officinalis L.). Adv Environ Res. 2011; 5: 639-646.

32. Mahdavi M, Jouri MH, Mahmoudi J, Rezazadeh F, Mahzooni-Kachapi SS. Investigating the altitude effect on the quantity and quality of the essential oil in Tanacetum polycephalum Sch.-Bip. polycephalum in the Baladeh region of Nour. Iran Chin J Nat Med. 2013; 11: 553-559.

33. Vázquez-Flota F, Carrillo-Pech M, Minero-García Y, Miranda-Ham ML. Alkaloid metabolism in wounded Catharanthus roseus seedlings. Plant Physiol Biochem. 2004; 42: 623-628.

34. Ghelardini C, Galeotti N, Mannelli LC, Mazzanti G, Bartolini A. Local anaesthetic activity of $\beta$-caryophyllene. II Farmaco. 2001; 56: 387-389.

35. Leonhardt V, Leal-Cardoso JH, Lahlou S, Albuquerque AAC, Porto RS, Celedônio NR, Oliveira AC, Ferreira RF, Silva LP, Garcia-Teófilo TMN, Silva APFS, Magalhães PJC, Duarte GP, Coelho-de-Souza AN. Antispasmodic effects of essential oil of Pterodon polygalaeflorus and its main constituent $\beta$-caryophyllene on rat isolated ileum. Fundam Clin Pharmacol. 2010; 24: 749-758.

36. Santos TG. Chemical characterization of essential oils from Drimys angustifolia miers (Winteraceae) and antibacterial activity of their major compounds. J Braz Chem Soc. 2013; 24: 164-170.

37. Silva L, Oniki GH, Agripino DG, Moreno PR, Young MCM, Mayworm MAS, Ladeira AM. Biciclogermacreno, resveratrol e atividade antifúngica em extratos de folhas de Cissus verticillata (L.) Nicolson \& Jarvis (Vitaceae). Rev Bras Farmacogn. 2007; 17: 361-367.

38. Tasic S, Tasic NM. Cladosporium spp.-cause of opportunistic mycoses. Acta Fac Med Naiss. 2007; 24: 15-19.

39. Sabulal B, Dan M, Kurup R, Pradeep NS, Valsamma RK, George V. Caryophyllene-rich rhizome oil of Zingiber nimmonii from South India: chemical characterization and antimicrobial activity. Phytochemistry. 2006; 67: 24692473.

40. Veiga-Junior VF, Rosas EC, Carvalho MV, Henriques MGMO, Pinto AC. Chemical composition and antiinflammatory activity of copaiba oils from Copaifera cearensis Huber ex Ducke, Copaifera reticulata Ducke and Copaifera multijuga Hayne-a comparative study, J Ethnopharmacol. 2007; 112: 248-254.

41. Sobrinho ACN, Souza EB, Rocha MFG, Albuquerque MRJR, Bandera PN, Santos HS, Pereira R, Morais SM, Fontenelle ROS, Cavalcante CSP. Cytotoxicity, antifungal and antioxidant activities of the essential oil from Eupatorium ballotifolium Kunth (Asteraceae). Afr J Pharm Pharmacol. 2016; 10: 346-355.

42. Skold M, Karlberg AT, Matura M, Borje A. The fragrance chemical b-caryophyllene-air oxidation and skin sensitization. Food Chem Toxicol. 2006; 44: 538-545.

43. Pichette A, Larouche P-L, Lebrun M, Legault J. Composition and antibacterial activity of Abies balsamea essential oil. Phytother Res. 2006; 20: 371-373

44. Alma MH, Mavi A, Yildirim A, Digrak M, Hirata T. Screening chemical composition and in vitro antioxidant and antibacterial activities of the essential oils from Origanum syriacum L. growing in Turkey. Biol Pharm Bull. 2003; 26: $1725-1729$.

45. Lourens AC, Reddy D, Baser KH, Viljoen AM, Van Vuuren SF. In vitro biological activity and essential oil composition of four indigenous South African Helichrysum species. J Ethnopharmacol. 2004; 95: 253-258

46. Hiruma M, Kano R, Sugita T, Mochizuki T, Hasegawa A, Hiruma M. Epidemiological aspects of Trichophyton rubrum var. raubitschekii in Japan. J Dermatol. 2012; 39: 1000-1001.

47. Gupta AK, Nakrieko KA. Trichophyton rubrum DNA strain switching increases in patients with onychomycosis failing antifungal treatments. Br J Dermatol. 2015; 172: 74-80.

48. Skaltsa HD, Demetzos C, Lazari D, Sokovic M. Essential oil analysis and antimicrobial activity of eight Stachys species from Greece. Phytochemistry. 2003; 64: 743-752.

49. Bougatsos C, Ngassapa O, Runyoro DK, Chinou IB. Chemical composition and in vitro antimicrobial activity of the essential oils of two Helichrysum species from Tanzania. Z Naturforsch C Bio Sci. 2004; 59: 368-372.

50. Tampieri MP, Galuppi R, Macchioni F, Carelle MS, Falcioni L, Cioni PL, Morelli I. The inhibition of Candida albicans by selected essential oils and their major components. Mycopathologia. 2005; 159: 339-345.

51. Demirci B, Baser KHC, Tabanca N, Wedge DE. Characterization of volatile constituents of Haplopappus greenei and studies on the antifungal activity against phytopathogens. J Agric Food Chem. 2006; 54: 3146-3150.

52. Nogueira LFB, Morais EC, Brito MAD, Santos BS, Vale DL, Lucena BFF, Figueredo FG, Guedes GMM, Tintino SR, Souza CES, Nogueira RBSS, Matias EFF, Morais-Braga MFB, Cunha EVL, Lima MA, Coutinho HD. Evaluation of antibacterial, antifungal and modulatory activity of methanol and ethanol extracts of Padina sanctae-crucis. Afr Health Sci. 2014; 14: 372-376.

53. Alves CQ, David JM, David JP, Bahia MV, Aguiar RM. Métodos para determinação de atividade antioxidante in vitro em substratos orgânicos. Quim Nova. 2010; 33: 2202-2210.

54. Kulisic T, Radonic A, Katalinic V, Milos M. Use of different methods for testing antioxidative activity of oregano essential oil. Food Chem. 2004; 85: 633-40.

55. Silva FA, Borges MFM, Ferreira MA. Métodos para avaliação do grau de oxidação lipídica e da capacidade antioxidante. Quim Nova. 1999; 22: 94-103. 
56. Xu YJ, Sun SB, Sun LM, Qiu DF, Liu XJ, Jiang ZB, Yuan CS. Quinic acid esters and sesquiterpenes from Sonchus arvensis. Food Chem. 2008; 111: 92-97.

57. Sghaier MB, Skandrani I, Nasr N, Franca M-GD, Chekir-Ghedira L, Ghedira K. Flavonoids and sesquiterpenes from Tecurium ramosissimum promote antiproliferation of human cancer cells and enhance antioxidant activity: A structure-activity relationship study. Environ Toxicol Pharmacol. 2011; 32: 336-348.

58. Calleja MA, Vieites JM, Montero-Meterdez T, Torres MI, Faus MJ, Gil A, Suárez A. The antioxidant effect of $\beta$ caryophyllene protects rat liver from carbon tetrachloride-induced fibrosis by inhibiting hepatic stellate cell activation. Br J Nutr. 2013; 109: 394-401.

59. Candan F, Unlu M, Tepe B, Daferera D, Polissiou M, Sökmen A, Akpulat HA. Antioxidant and antimicrobial activity of the essential oil and methanol extracts of Achillea millefolium subsp. millefolium Afan. (Asteraceae). J Ethnopharmacol. 2003; 87: 215-220.

60. Erasto P, Grierson DS, Afolayan AJ. Bioactive sesquiterpene lactones from the leaves of Vernonia amygdalina. J Ethnopharmacol. 2006; 106: 117-120.

61. Atangwho IJ, Egbung GE, Ahmad M, Yam MF, Asmawi MZ. Antioxidant versus anti-diabetic properties of leaves from Vernonia amygdalina Del. growing in Malaysia. Food Chem. 2013; 141: 3428-3434.

62. Hira A, Dey SK, Howlader MSI, Ahmed A, Hossain H, Jahan IA. Anti-inflammatory and antioxidant activities of ethanolic extract of aerial parts of Vernonia patula (Dryand.) Merr. Asian Pac J Trop Biomed. 2013; 3: 798-805.

63. Rajamurugan $\mathrm{R}$, Selvaganabathy $\mathrm{N}$, Kumaravel $\mathrm{S}$, Ramamurthy $\mathrm{CH}$, Sujatha $\mathrm{V}$, Suresh-Kumar $\mathrm{M}$, Thirunavukkarasu C. Identification, quantification of bioactive constituents, evaluation of antioxidant and in vivo acute toxicity property from the methanol extract of Vernonia cinerea leaf extract. Pharm Biol. 2011; 49: 13111320.

64. Silva JB, Temponi VS, Gasparetto CM, Fabri RL, Aragão DMO, Pinto NCC, Ribeiro A, Scio E, Del-Vechio-Vieira G, Sousa OV, Alves MS. Vernonia condensata Baker (Asteraceae): A promising source of antioxidants. Oxid Med Cell. Longev.2013; 1-9.

65. David JP, Meira M, David JM, Brandão HN, Branco A, Agra MF, Barbosa MRV, Queiroz LP, Giulietti AM. Radical scavenging, antioxidant and cytotoxic activity of Brazilian Caatinga plants. Fitoterapia. 2007; 78: 215-218.

66. Mclaughlin JL, Rogers LL, Anderson JE. The use of biological assays to evaluate botanicals. Drug Inf J. 1998; 32: 513-524.

67. Costa ES, Dolabela MF, Póvoa MM, Oliveira DJ, Müller AH. Estudos farmacognósticos, fitoquímicos, atividade antiplasmódica e toxicidade em Artemia salina de extrato etanólico de folhas de Montrichardia linifera (Arruda) Schott, Araceae. Rev Bras Farmacogn. 2009; 19: 834-838.

68. Daruliza KM, Fernandez L, Jegathambigai R, Sasidharan S. Anti-Candida activity and brine shrimp toxicity assay of Ganoderma boninense. Eur Rev Med Pharmacol Sci. 2012; 16: 43-48.

69. Miyazaki CMS, Hirota BCK, Lima CP, Verdam MCS, Paula CS, Chaves S, Pavan PMN, Miguel MD, Miguel OG. Coumarin isolation and comparative study of biological activities of Pterocaulon alopecuroides DC and Pterocaulon lorentzii Malme. Int J Phytomedicine. 2013; 5: 298-301.

(C) 2020 by the authors. Submitted for possible open access publication under the terms and conditions of the Creative Commons Attribution (CC BY NC) license (https://creativecommons.org/licenses/by-nc/4.0/). 